\title{
Phenotypic Identification and Phylogenetic Characterization of Uropathogenic Escherichia coli in Symptomatic Pregnant Women With Urinary Tract Infections in South-Western Nigeria
}

\author{
Aregbesola Oladipupo Abiodun ${ }^{1}$, Oluduro Anthonia Olufunke ${ }^{1}$, Fashina Christina Dunah ${ }^{1} \&$ \\ Famurewa Oladiran ${ }^{2}$ \\ ${ }^{1}$ Department of Microbiology, Faculty of Science, Obafemi Awolowo University, Ile-Ife 220005, Nigeria \\ ${ }^{2}$ Department of Microbiology, Ekiti State University, P.M.B. 5363, Ado-Ekiti 36001, Nigeria \\ Correspondence: Oluduro Anthonia Olufunke, Department of Microbiology, Faculty of Science, Obafemi \\ Awolowo University, Ile-Ife 220005, Nigeria. Tel: 234-806-937-9885. E-mail: aoluduro2003@yahoo.co.uk
}

\author{
Received: August 10, 2014 Accepted: August 30, 2014 Online Published: September 20, 2014 \\ doi:10.5539/ijb.v6n4p145 URL: http://dx.doi.org/10.5539/ijb.v6n4p145
}

\begin{abstract}
The study reports the characterization of uropathogenic E. coli (UPEC) in urine samples of pregnant women with confirmed urinary tract infections (UTIs) in Ondo and Ekiti States, Nigeria.

Voided mid-stream urine samples were cultured on eosin methylene blue agar plates at $37^{\circ} \mathrm{C}$ and identified by conventional biochemical tests. Antibiotic susceptibility testing of isolates was by Kirby-Bauer's disc diffusion technique. Phylogenetic typing of the isolates was by multiplex polymerase chain reaction (PCR).

The occurrence of UPEC in pregnant women in age group 25-35 years $(66.0 \%)$ was high. Two hundred and sixty four uropathogenic E. coli comprising 133 (50.38\%) in Ondo and 131 (49.62\%) in Ekiti States were recovered from 400 samlpes analyzed. In all, prevalence of UTIs with positive cultures was $66.0 \%$. Escherichia coli only was $56.5 \%$, mixed-infection $(9.5 \%)$, non- $E$. coli infection (12.5\%) and no growth (21.5\%). Resistance to antibiotics was high with diverse multiple antibiotic resistance patterns. Greater percentage of the screened representative UPEC isolates belonged to phylogenetic group D (65.0\%), group A (28.0\%), group B1 (6.7\%) and none to group B2.

Escherichia coli belonging to phylogenetic group D appears to be a predominant uropathogen in this study area. Presence of chuA gene in most of the isolates shows the significance of iron acquisition in the pathogenesis and urovirulence of UPEC.
\end{abstract}

Keywords: UPEC, Urinary tract infection, symptomatic, pregnant women, extra-intestinal pathogenic E. coli

\section{Introduction}

Urinary tract infections (UTIs) are infections caused by the presence and growth of microorganisms anywhere in the urinary tract and are among the most common bacterial infections found in humans. Uropathogenic E. coli are implicated in $70-90 \%$ of community acquired UTIs and $50 \%$ of nosocomial UTIs. The virulence factors and clinical picture presented by UPEC infections indicate that these pathogens are extra-intestinal pathogenic $E$. coli (ExPEC) strains (Johnson \& Russo, 2005). Individuals with UTI will have a significant number of pathogens in the urinary system. Pathogens may be present in the bladder (cystitis), kidneys (pyelonephritis), urine (bacteriuria) or prostrate (prostatitis) (Marrs et al., 2005). Individuals with increased risk of UTIs include infants, pregnant women and the elderly. Patients with spinal cord injuries, diabetes, multiple sclerosis, urinary catheters, HIV/AIDS or underlying urologic abnormalities are also at risk (Foxman, 2002). Since the genitourinary tract is close to the rectum, faecal bacteria can ascend the urethra into the bladder. If there is a reflux of urine from the infected bladder to the ureters, the kidney may be infected. The ascending route from the faecal site is considered as the major means of transmission of UTI-inducing ExPEC to the urinary tract. About $20 \%$ of all UTIs cases occur in men while $50-60 \%$ of women will have at least one episode of UTI during their lifetime (Griebling, 2005). There is a tendency of recurrence of UTIs in about $25-30 \%$ of women after the initial infection due to either re-infection or recrudescence (Bower et al., 2005) Escherichia coli can be broadly classified into three groups: commensal E. coli which constitute the normal floral of the intestine; intestinal pathogenic $E$. coli which 
causes various infections in the intestine and ExPEC which elicits infections in various parts of the body excluding the intestine (Diard et al., 2010). Extra-intestinal uropathogenic E. coli strains are defined as E. coli with enhanced ability to cause infections outside the intestinal tract, such as in the bloodstream, cerebrospinal fluid or urinary tract of the host (Diard et al., 2010). Virulence factors associated with ExPEC include: adhesins, toxins (hemolysin and cytotoxic necrotizing factor), siderophores (aerobactin), host defense avoidance mechanisms/polysaccharides coatings (group II capsules and biofilm formation) and uropathogenic-specific protein (usp) (Arisoy et al., 2006; Skjøt-Rasmussen et al., 2011). Antimicrobial agents of various classes are widely used for therapeutic intervention of urinary tract infections caused by UPEC, but it is also used for prophylactic therapy. However, irrational used of antibiotics as a therapeutic agents of bacterial infections lead to the emergence of resistant bacteria (Morioka et al., 2005). Acquired resistance to antimicrobial drugs is becoming more prevalent among $E$. coli and other pathogens in this region.

There is no clear consensus in the literature on the optimal antimicrobial choice or duration of therapy for UTI during pregnancy. In light of the possible adverse effects of antimicrobials, higher quality research is needed to better understand the direct and indirect consequences of antimicrobial exposure early in life and prudent antimicrobial use is extremely important during pregnancy and early childhood (Schneeberger et al., 2014). Studies exploring cost-effective diagnostic tools at the point of care and non-antimicrobial options to prevent or treat UTIs are needed to limit unnecessary treatment of bacteriuria in pregnancy (Abbo \& Hooton, 2014).

Traditional typing of $E$. coli is based on phenotypes, serotype, biotype, phage-typing or antibiotype. Molecular techniques used for the characterization of E. coli include; Pulsed-field gel electrophoresis (PFGE) which is considered a gold standard among molecular typing methods for a variety of clinically important bacteria, other molecular methods include: phylogenetic typing, amplified fragment length polymorphism (AFLP), random amplification of polymorphic DNA (RAPD), Variable-Number Tandem Repeat (VNTR) typing, Multi-locus sequence typing (MLST), comparative genomic hybridization, single-nucleotide polymorphisms (SNPs), optical mapping, and whole genome sequencing (Sabat et al., 2013).

Intestinal E. coli has been studied extensively to the molecular level. However, there is limited information on the phylogenetic lineages of uropathogenic $E$. coli in Nigeria. No attempt has been made at the molecular level to determine whether E. coli implicated in urinary tract infections in Nigeria are from the same or different clone, hence this study.

The study provides information on the susceptibility to various classes of antibiotics and clonal groups that exist within extraintestinal UPEC in pregnant women with UTIs in the study areas.

\section{Materials and Methods}

\subsection{Study Area}

The study areas include Ekiti and Ondo States, Southwestern Nigeria. Ekiti and Ondo States are situated entirely within the tropics. Ekiti State is located between longitudes $40^{\circ} 51^{\prime}$ and $50^{\circ} 451^{\prime}$ east of the Greenwich meridian and latitudes $70^{\circ} 151^{\prime}$ and $80^{\circ} 51^{\prime}$ north of the Equator. Ondo State lies between longitudes 4"30" and 6" East of the Greenwich Meridian, 5" 45" and 8" 15" North of the Equator. The selected hospitals in Ondo State included; State Specialist Hospital Ondo, State Specialist Hospital Akure, General Hospital, Ile-Oluji, Ondo States while those of Ekiti State included: Ekiti State University Teaching Hospital, Ado-Ekiti, Federal Medical Centre, Ido-Ekiti and Aiyegbaju community Health Centre, Aiyegbaju.

\section{2 Collection of Sample}

With the permission from the Chief Medical Director and laboratory Scientists of the selected hospitals, verbal informed consent of pregnant women with confirmed urinary tract infections at the selected hospitals in Ondo and Ekiti States was obtained before sample collection. Four hundred early morning voided mid-stream urine samples comprising 200 in each state were obtained and transported to the Department of Microbiology laboratory, Obafemi Awolowo University, Ile-Ife, on ice, where the samples were analysed. Sample collection was between June, 2011 and November, 2012.

\subsection{Isolation of E. coli and Antibiotic Susceptibility of Isolates}

Escherichia coli isolates were presumptively identified by colonial morphology on Eosin methylene blue (EMB) agar ((Oxoid, UK)), incubated at $37^{\circ} \mathrm{C}$ for $24 \mathrm{~h}$. Distinct greenish metallic sheen colonies on the EMB agar plates were further identified and confirmed by conventional biochemical tests (Farmer, 1999).

The antibiogram of the isolates was determined on Mueller-Hinton agar (LAB-M, UK) by the disk diffusion method (Clinical and Laboratory Standards Institute, 2012). The antibiotics tested and their concentrations (in $\mu \mathrm{g}$ ) 
include; cefadroxil (30), ampicillin (10), nalidixic acid (30), cefepime (30), amoxicillin-clavulanate (20/10), cefuroxime (30), ceftazidime (30), cefotaxime (30) (Oxoid, UK), amoxicillin (30), gentamicin (10), ofloxacin (5), ciprofloxacin (30), tetracycline (25), augmentin (30), ceftriazole (30), nitrofurantoin (300), cotrimoxazole (30), and pefloxacin (30) (Fondos, Nigeria). The antibiotic disks were firmly placed on sterile Mueller-Hinton Agar (MHA) plates previously seeded with a $24 \mathrm{~h}$ old culture of the isolate $\left(10^{6} \mathrm{CFU} / \mathrm{ml}\right.$ of $0.5 \mathrm{McF}$ arland Standard). The plates were incubated at $37^{\circ} \mathrm{C}$ for $24 \mathrm{~h}$ and diameter of zones of inhibition was compared (Clinical and Laboratory Standards Institute, 2012). Escherichia coli ATCC 25922 was used as reference. Multiple antibiotic resistant (MAR) isolates were defined as resistance to greater than or equal to three $(\geq 3)$ classes of the antibiotics tested.

\section{4 Phylogenetic Typing}

Phylogenetic grouping of the selected E. coli isolates was determined by triplex/multiplex PCR-based phylotyping (Clermont et al., 2000). The DNA of the selected isolates was extracted by heat lysis. The isolates were harvested from a $1.5 \mathrm{ml}$ of an overnight Luria-Bertani broth culture by centrifugation in a refrigerated micro-centrifuge (Eppendorf Micro-centrifuge Model 5418, Germany) at $14000 \mathrm{rpm}$ for $7 \mathrm{~min}$, the supernatant was decanted and the cells were washed in $1 \mathrm{ml}$ of sterile distilled water. The supernatant was decanted and the

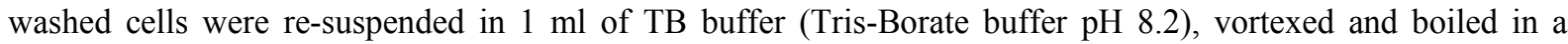
thermomixer incubator (Eppendorf thermomixer R mixer incubator model $\mathrm{C} 108115$ ), at $95^{\circ} \mathrm{C}$ for $10 \mathrm{~min}$. The lysates were centrifuged in a refrigerated microcentrifuge (Eppendorf Micro-centrifuge Model 5418, Germany) at $14000 \mathrm{rpm}$ for $10 \mathrm{~min}$ and the supernatant was transferred into a new $1.5 \mathrm{ml}$ Eppendorf tube and stored at $-20^{\circ} \mathrm{C}$ as a template DNA stock. The quality of the extracted DNA samples was checked using a nano-drop spectrophotometer (Nano-drop ND-1000 UV-Vis spectrophotometer) and the absorbance ratio of 260nm and $280 \mathrm{~nm}$ was estimated. The extracted DNA samples of the test isolates were amplified by multiplex polymerase chain reaction using the primers $c h u A$ and $y j a A$ genes and the DNA fragment TspE4.C2 with molecular weights of 279,211 and $152 \mathrm{~kb}$, respectively. A $20 \mu \mathrm{l}$ of the PCR reaction mixture $\left(13.15 \mu 1\right.$ of $\mathrm{ddH}_{2} \mathrm{O}, 4 \mu \mathrm{l}$ of master mix, $0.2 \mu \mathrm{l}$ of each primers, 0.15 unit of Taq polymerase and $1.5 \mu 1$ of the DNA sample) was amplified in a PCR machine (Eppendorf Mastercycler pro). The amplification conditions include: denaturation for 4 min at $94^{\circ} \mathrm{C}, 30$ cycles of $5 \mathrm{~s}$ at $94^{\circ} \mathrm{C}$ and $10 \mathrm{~s}$ at $59^{\circ} \mathrm{C}$ and a final extension step of $5 \mathrm{~min}$ at $72^{\circ} \mathrm{C}$. The PCR products were electrophoresed on a $1.5 \%$ agarose gel, stained with $1 \%$ ethidium bromide and run at $80 \mathrm{~V}$ for $2 \mathrm{~h}$ and scanned with ultraviolet trans-illuminator. The phylogenetic grouping was done using the dichotomous decision tree designed by Clermont et al. (2000), based on the presence and absence of these three markers as follows; group

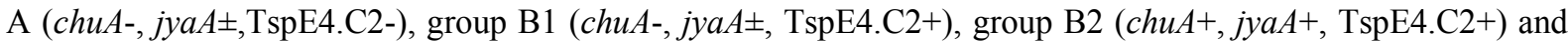
group D (chuA+, jyaA-, TspE4.C2 \pm ). The primers sequences are given below:

ChuA-5'-GACGAACCAACGGTCAGGAT-3' forward

ChuA- 5'-TGCCGCCAGTACCAAAGACA-3' reverse

yjaA- 5'-TGAAGTGTCAGGAGACGCTG-3' forward

jyaA- 5'-ATGGAGAATGCGTTCCTCAAC-3' reverse

TspE4.C2- 5'-GAGTAATGTCGGGGCATTCA-3' forward

TspE4.C2- 5'-CGCGCCAACAAAGTATTACG-3' reverse

\section{5 Statistical Analysis}

Significant differences and relationship between various data obtained were compared using SPSS 17 version.

\section{Results}

The age distribution of the pregnant women with confirmed UTIs in Ondo and Ekiti States is depicted by figure 1. The age distribution of the subjects involved in the study ranged from 19-52 years. Out of the 200 samples obtained in Ondo State, 41 (20.5\%) patients were less than 25 years, 129 (24.5\%) were between ages 25 - 35 while $30(15.9 \%)$ patients were above 35 years. Similarly, in Ekiti State, 49 (24.5\%) patients were below the age $25,134(67.0 \%)$ were between $25-35$ and 17 (8.5\%) patients were above the age of 35 . In all, patients below age 25 were $22.50 \%$, age group $25-35(66.0 \%)$ and above 35 years $(11.75 \%)$. There is no significant statistical difference in the age distribution of the subjects in these study areas $(\mathrm{P}>0.05)$.

The occurrence of UPEC in the samples investigated is presented in table 1. A total of 264 uropathogenic E. coli comprising $133(50.38 \%)$ in Ondo and 131 (49.62\%) in Ekiti States were recovered. In all, prevalence of UTIs with positive cultures was $66.0 \%$. From the samples analyzed, E. coli (mono-culture) was recovered from $56.5 \%$, mixed-infection (9.5\%), non-E. coli infection (12.5\%) and no growth (21.5\%) (Table 1). 


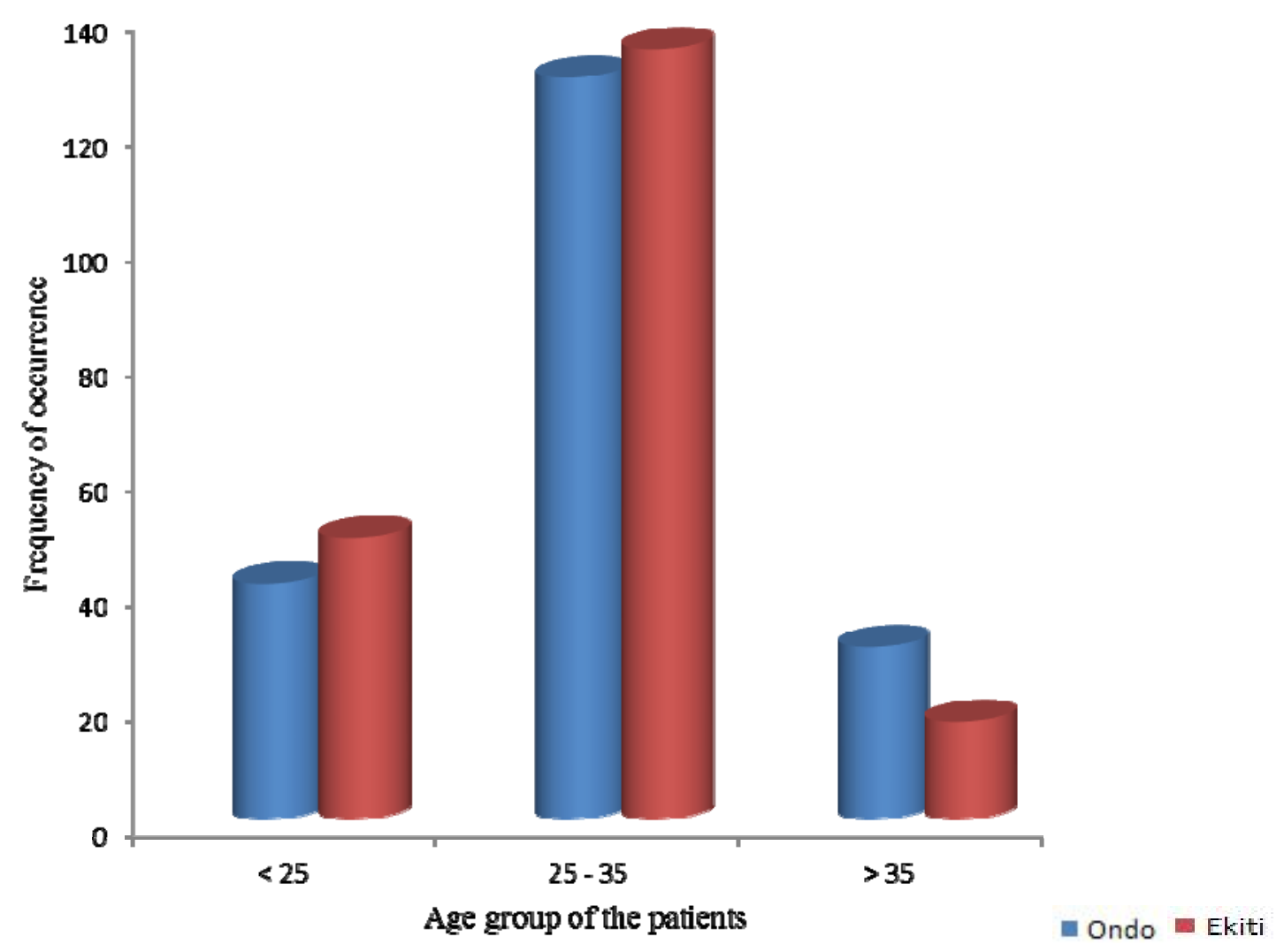

Figure 1. Age distribution of the pregnant women with confirmed urinary tract infection in Ondo and Ekiti States

Table 1. Occurrence of uropathogenic Escherichia coli in urine samples of pregnant women with confirmed UTIs in Ondo and Ekiti States, Nigeria

\begin{tabular}{lccccc}
\hline \multirow{2}{*}{ Culture } & Frequency of occurrence & Total & Percentage (\%) \\
\cline { 2 - 3 } & Ondo State & Ekiti State & n=400 & Pern \\
\hline Escherichia coli growth (Mono culture) & 111 & 115 & 226 & 56.5 \\
Escherichia coli with other bacteria (mixed culture) & 22 & 16 & 38 & 9.5 \\
Non-E. coli culture (negative culture) & 29 & 21 & 50 & 12.5 \\
No growth & 39 & 47 & 86 & 21.5 \\
\hline
\end{tabular}

$\mathrm{n}=$ number of samples.

The prevalence of antibiotic resistance among the UPEC isolates from both Ondo and Ekiti States is presented in table 2. In all, $76.6 \%$ of the isolates were resistant to $\beta$-lactams class of antibiotics, fluoroquinolones $(62.6 \%)$, aminoglycosides $(62.0 \%)$, nitrofurantoin $(70.0 \%)$, tetracyclines $(95.0 \%)$ and sulphonamides/trimethoprim $(83.3 \%)$. There is no significant statistical difference in the prevalence of antibiotic resistance $(p<0.05)$ in both Ondo and Ekiti States. 
Table 2. Prevalence of antibiotic resistance among UPEC isolated from urine samples of UTIs pregnant women in Ondo and Ekiti States

\begin{tabular}{|c|c|c|c|c|c|c|}
\hline \multirow[t]{2}{*}{ Classes of antibiotics } & \multirow[t]{2}{*}{ Specific antibiotics } & \multicolumn{2}{|c|}{ Occurrence $(n=264)$} & \multirow{2}{*}{$\begin{array}{l}\text { Overall } \\
(\mathrm{R})\end{array}$} & \multirow{2}{*}{$\begin{array}{c}\% \\
(\mathrm{R})\end{array}$} & \multirow{2}{*}{$\begin{array}{c}\text { Average } \\
\%(\mathrm{R})\end{array}$} \\
\hline & & $\begin{array}{c}\text { Ondo } \\
(\mathrm{n}=133)\end{array}$ & $\begin{array}{c}\text { Ekiti } \\
(\mathrm{n}=131)\end{array}$ & & & \\
\hline \multirow[t]{9}{*}{$\beta$-Lactams } & Augmentin $(30 \mu \mathrm{g})$ & 87 & 91 & 178 & 67.0 & \multirow{9}{*}{76.6} \\
\hline & Amoxicillin $(25 \mu \mathrm{g})$ & 90 & 99 & 189 & 72.0 & \\
\hline & Ampicillin $(10 \mu \mathrm{g})$ & 113 & 107 & 220 & 83.0 & \\
\hline & Ceftriaxone $(30 \mu \mathrm{g})$ & 101 & 127 & 228 & 86.4 & \\
\hline & Cefadroxil $(30 \mu \mathrm{g})$ & 129 & 130 & 258 & 98.0 & \\
\hline & Cefotaxime $(30 \mu \mathrm{g})$ & 85 & 95 & 180 & 68.0 & \\
\hline & Cefepime $(30 \mu \mathrm{g})$ & 30 & 46 & 76 & 29.0 & \\
\hline & Ceftazidime $(30 \mu \mathrm{g})$ & 128 & 123 & 251 & 95.0 & \\
\hline & Cefuroxime $(30 \mu \mathrm{g})$ & 121 & 120 & 241 & 91.0 & \\
\hline \multirow[t]{4}{*}{ Fluoroquinolones } & Nalidixic acid $(30 \mu \mathrm{g})$ & 85 & 93 & 178 & 67.0 & \multirow{4}{*}{62.6} \\
\hline & Ciprofloxacin $(10 \mu \mathrm{g})$ & 76 & 90 & 166 & 63.0 & \\
\hline & Ofloxacin $(5 \mu \mathrm{g})$ & 78 & 80 & 158 & 60.0 & \\
\hline & Pefloxacin $(10 \mu \mathrm{g})$ & 94 & 101 & 195 & 60.2 & \\
\hline Aminoglycosides & Gentamicin $(10 \mu \mathrm{g})$ & 62 & 102 & 164 & 62.0 & 62.0 \\
\hline Nitrofurantoins & Nitrofurantoin $(300 \mu \mathrm{g})$ & 89 & 95 & 184 & 70.0 & 70.0 \\
\hline Tetracyclines & Tetracycline $(30 \mu \mathrm{g})$ & 126 & 124 & 250 & 95.0 & 95.0 \\
\hline Sulphonamides/Trimethroprim & Cotrimoxazole $(25 \mu \mathrm{g})$ & 100 & 120 & 220 & 83.3 & 83.3 \\
\hline
\end{tabular}

Key: R: resistance; UTI: urinary tract infection.

Table 3 shows the multiple antibiotic resistance (MAR) profile of UPEC recovered from pregnant women with confirmed UTI in Ondo and Ekiti States. Multiple antibiotic resistance is defined as resistance to three or more different classes of the antibiotics tested. Ninety-eight (40.2\%) of the isolates were resistant to all the six classes of antibiotics tested, $87(35.7 \%)$ to five, $44(18.0 \%)$ and $15(6.1 \%)$ to four and three classes of antibiotics, respectively.

The multiple antibiotic resistance patterns (MAR) exhibited by the UPEC isolates are presented in table 4 . Diversities in MAR patterns were observed among the isolates. Eighteen different MAR patterns were displayed with MAR phenotype $\left(A U G^{R} N A L^{R} G^{R} N^{R} T^{R} T^{R} \operatorname{NIT}^{R} C^{2} T^{R}\right.$ ) appearing the most frequent (Table 4).

Table 3. Prevalence of multiple antibiotic resistant (MAR) uropathogenic E. coli isolated from the urine samples of pregnant women with confirmed urinary tract infections in Ondo and Ekiti States

\begin{tabular}{|c|c|c|c|c|c|}
\hline \multirow{2}{*}{$\begin{array}{l}\text { Number of } \\
\text { of antibiotics }\end{array}$} & \multirow{2}{*}{ classes } & Occurrence & $(\mathrm{n}=244)$ & \multirow[t]{2}{*}{ Total } & \multirow{2}{*}{$\begin{array}{l}\% \text { of isolates } \\
\text { with MARs }\end{array}$} \\
\hline & & Ondo $(\mathrm{n}=124)$ & Ekiti $(n=126)$ & & \\
\hline 6 & & $35(28.2)^{*}$ & $63(50.0)$ & 98 & 40.2 \\
\hline 5 & & $37(29.8)$ & $0(39.68)$ & 87 & 35.7 \\
\hline 4 & & $36(29.0)$ & $8(6.35)$ & 44 & 18.0 \\
\hline 3 & & $13(10.5)$ & $2(1.58)$ & 15 & 6.1 \\
\hline
\end{tabular}

Key: $\mathrm{MAR}=$ Multiple antibiotic resistance, $(\%)^{*}$ percentage of MAR on State basis. 
Table 4. The multiple antibiotic resistance (MAR) phenotypes of uropathogenic E. coli isolated from pregnant women with confirmed UTIs in Ondo and Ekiti States

\begin{tabular}{|c|c|c|c|}
\hline $\begin{array}{l}\text { Number of classes of } \\
\text { antibiotics }\end{array}$ & $\begin{array}{l}\text { Multiple antibiotic resistance phenotypes of } \\
\text { the isolates }\end{array}$ & Frequency & Overall (\%) \\
\hline & AUG NAL TET & 11 & \\
\hline & & 1 & \\
\hline \multirow[t]{8}{*}{3} & AUG TET COT & 1 & $15(6.14)$ \\
\hline & & 1 & \\
\hline & AUG NAL COT & 1 & \\
\hline & AUG NIT COT & & \\
\hline & GEN TET & & \\
\hline & AUG NAL TET COT & 16 & \\
\hline & AUG NAL GEN TET & 4 & \\
\hline & AUG GEN TET COT & 5 & \\
\hline \multirow[t]{8}{*}{4} & & 2 & $44(18.0)$ \\
\hline & GEN NIT TET & 4 & \\
\hline & & 7 & \\
\hline & AUG NAL NIT COT & 6 & \\
\hline & AUG NAL NIT TET & & \\
\hline & AUG NIT TET COT & & \\
\hline & AUG GEN NIT TET COT & 5 & \\
\hline & AUG NAL GEN TET COT & 29 & \\
\hline \multirow[t]{5}{*}{5} & & 11 & $87(35.66)$ \\
\hline & NAL GEN NIT TET & 1 & \\
\hline & & 41 & \\
\hline & AUG NAL GEN NIT COT & & \\
\hline & AUG NAL NIT TET COT & & \\
\hline \multirow[t]{2}{*}{6} & AUG NAL GEN NIT TET COT & 98 & $98(40.2)$ \\
\hline & Total number of MAR phenotypes $=18$ & $\mathrm{~N}=244$ & \\
\hline
\end{tabular}

Key: $\mathrm{AUG}=$ Augmentiin $(30 \mu \mathrm{g}), \mathrm{NaL}=$ Nalidixic acid; GEN=Gentamicin $(10 \mu \mathrm{g})$; NIT=Nitrofurantoin $(300 \mu \mathrm{g})$; TET=Tetracycline $(30 \mu \mathrm{g}) ; \mathrm{COT}=$ Cotrimoxazole $(25 \mu \mathrm{g})$.

Phylogenetic distribution of 60 selected UPEC isolates in pregnant women with UTI in Ondo and Ekiti States is depicted by figure 2. Isolates were dominated by phylogenetic group D 39(65.0\%), group A 17 (28.0\%), group B1 4(6.7\%) and none belonged to group B2. Twenty-two of the isolates in phylogenetic group D were recovered from samples in Ekiti State and 17 in Ondo State. In phylogroup A, 10 isolates were recovered in Ondo State and 7 in Ekiti State. Three out of the 4 isolates in group B1 were recovered from Ekiti States and one from Ondo State (Figure 2). Plates 1a and b show the gel electrophoresis of the amplified ChuA, YjaA and TspE4C2 markers DNA and the molecular weight ranged from 152 to $279 \mathrm{bp}$. Fifteen $(51.7 \%)$ of the isolates contained chuA gene, yjaA (13.8\%) and TspC4.c2 b (31.0\%) genes. 


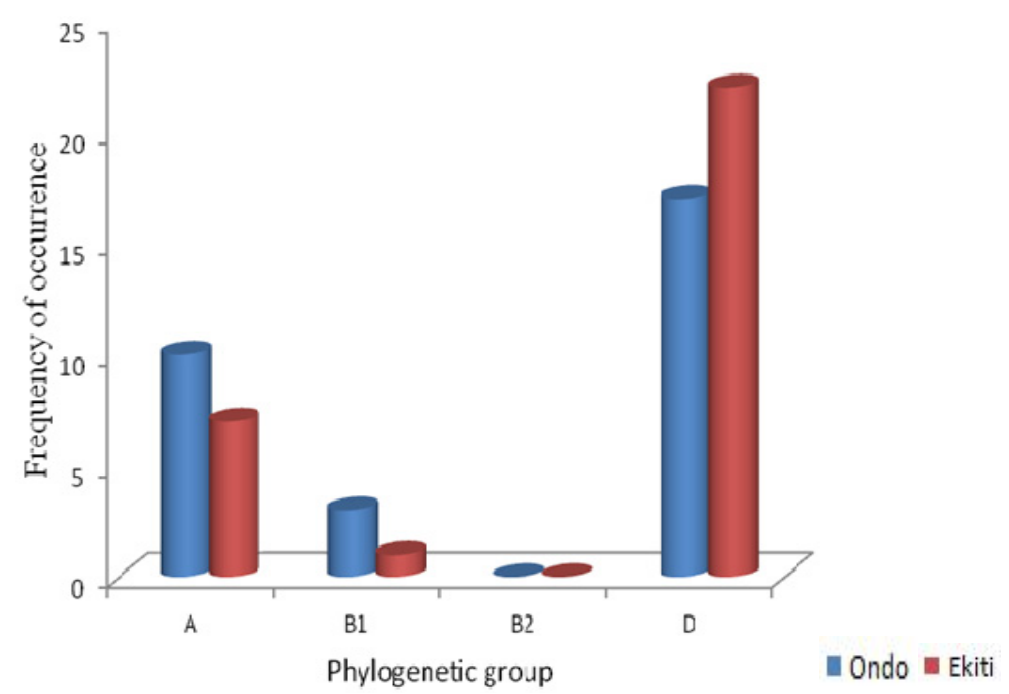

Figure 2. The distribution of the clonal types of uropathogenic E. coli in the study areas

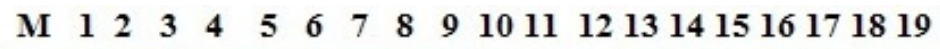

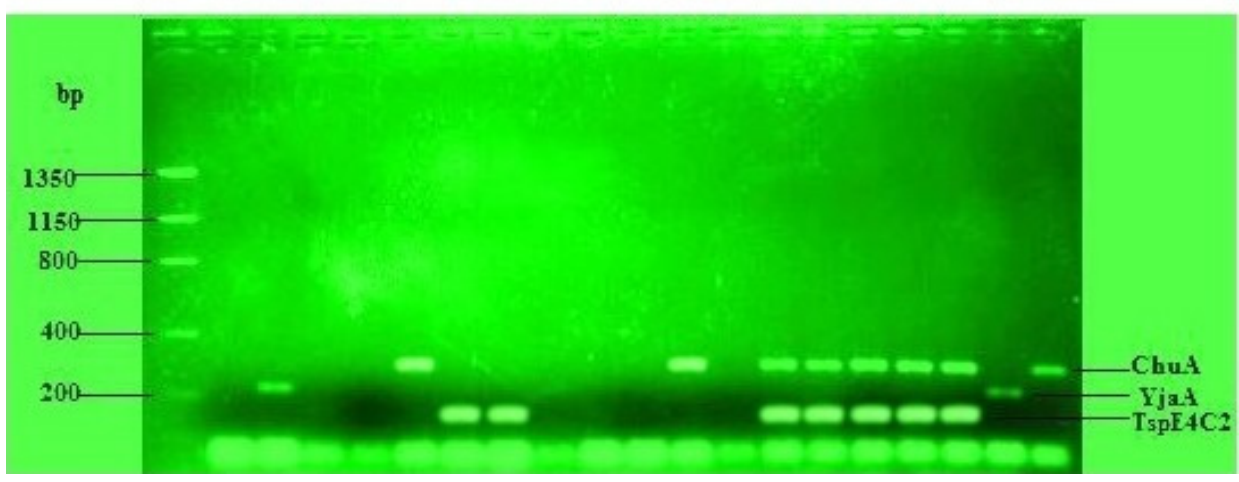

Plate 1a. Gel electrophoresis of ChuA, YjaA and TspE4C2 markers in uropathogenic E. coli isolates in pregnant women with confirmed UTIs in Ondo and Ekiti States

Key: Lane M= DNA marker; Lanes 1-19= the UPEC isolates. (Isolates in lanes 1, 2, 3, 4, 8, 9, 10, 12 and 18 belong to group A), $(5,11,13,14,15,16,17$ and 19 belong to Group D) while isolates 6 and 7 belong to group B.

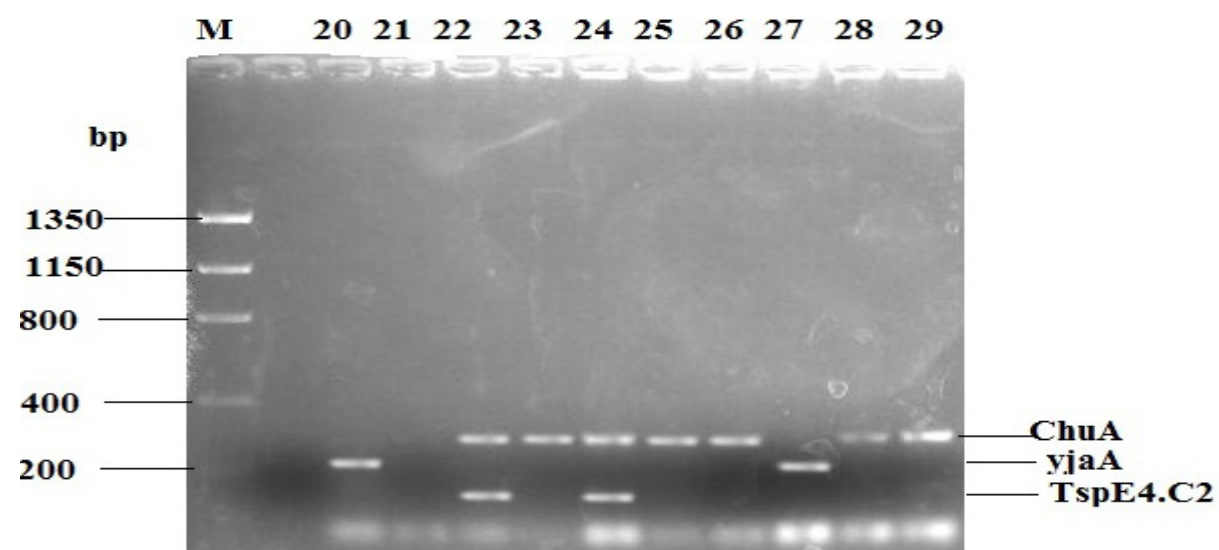

Plate 1b: Gel electrophoresis of ChuA, YjaA and TspE4C2 markers in UPEC isolates in pregnant women with confirmed UTIs in Ondo and Ekiti States

Key: Lane M= DNA marker; Lanes $20-29$ = the test isolates. Isolates on lanes 20 and 27 belong to group A while isolates on lanes 22, 23, 24, 25, 26, 28 and 29 belong to group D. 


\section{Discussion}

Prevalence of UTI in symptomatic pregnant women in the study areas is high among the age groups considered. This is similar to the findings reported by Abid et al. (2013) among pregnant patients with UTIs in Pakistan but higher than the percentages (49.4\%) reported in earlier studies by Manjula et al. (2013) in pregnant patients in India and $30 \%$ by Tamalli et al. (2013) in pregnant women who were followed up at different antenatal care clinic in Libya. The high prevalence of UTIs may be explained by sexual intercourse and pregnancy due to the normal physiologic changes induced by gestation which render pregnant women especially susceptible to these infections (National Institutes of Health, 2004; Kolawole et al., 2009).

Prevalence of UTIs in pregnancy among patients above 35 years in the study could be due to the fact that many women within these age groups are likely to have had children before the present pregnancy. Multiparty has been tagged a risk factor in acquiring bacteriuria in pregnancy (Tamalli et al., 2013). Since women in active sexual activities are believed to be prone to UTIs, sexual activity and certain contraceptive devices have been reported to increase the risk, moreover, women are mostly sexually active at the child bearing age (Sharma et al., 2009).

The recovery of UPEC (84\%) in the patients sampled agrees with the findings of Ehsan et al. (2013) who reported $84 \%$ occurrence of $E$. coli in UTIs episode in Iran. Prevalence of UPEC in this study is higher than earlier report in India where E. coli (56.79\%) predominates the pathogens recovered (Manjula et al., 2013), and $43.27 \%$ reported by Ehsan et al. (2013) as the most prevalent among pregnant women. The recovery of only species of $E$. coli from 226 of the patients suggests a mono-microbial nature of $E$. coli in UTIs.

The high resistance of the isolates to antibiotics in this study may be due to easy accessibility, prolonged use, and abuse. Studies worldwide show a noticeable increase in resistance to ciprofloxacin and other fluoroquinolones because ciprofloxacin is one of the most frequently prescribed fluoroquinolones for UTIs in adults due to its excellent activity on pathogens commonly encountered in complicated UTIs, most especially E. coli (Ehsan et al., 2013).

A study from Iran found $32.0 \%$ of the E. coli implicated in various UTI cases among pregnant patients resistant to ciprofloxacin (Kashef et al., 2010), and other studies from Singapore and Korea have reported ciprofloxacin resistance rates of about 25\% (Lee et al., 2011; Bahadin et al., 2011). However, in the present study, higher incidences of resistance to these antibiotics were recorded. The low resistance incidence recorded in earlier studies may be due to better antibiotic use policies in those areas, non-abuse and inaccessibility of these antibiotics in those countries. For instance, nitrofurantoin resistance rate was significantly low in Singapore and in Italy as reported by Bahadin et al. (2011) and Caracciolo et al. (2011), respectively, which is not the case in the present study which recorded high resistance rate. Prophylactic use of antibiotics and a history of drug usage have been identified as risk factors associated with antibiotic resistance (Yuksel et al., 2006; Ehsan et al., 2013). The present study also found majority of the UPEC to be multiple antibiotic resistant particularly to fluoroquinolones and other classes of antibiotics. Fluoroquinolone resistance without concurrent resistance to other classes of antibiotics is uncommon in this study; this scenario indicates the continued declension of the activities of these antibiotics against uropathogens. High prevalence of MAR strains obtained in this study is a possible indication that very large population of $E$. coli isolates might have been exposed to several antibiotics or antibiotics with similar targets/modes of action. The implication of this finding is that most of these pathogens can be voided into the environment including water bodies and possibly enter into the food chain. People living in and/or around these premises with little or no access to safe pipe-borne water may be tempted to drink from such water bodies polluted with urine samples of affected UTI patients. This may create a time bomb of epidemic for unsuspecting and or ignorant members of the community which may ingest such MAR-UPEC into their systems and would in no time lead to devastating public health consequences.

A link between strain phylogeny and virulence has been reported. Phylogenetic analysis have shown that $E$. coli strains fall into four main phylogenic groups; A, B1, B2 and D (Herzer et al., 1990) and that virulent extra-intestinal strains of E. coli belong mainly to groups B2 and D while commensal E. coli predominantly belongs to A and B1 phylogroups (Skjøt-Rasmussen et al., 2011). Phylogenetic group D has been recognized as the cause of community acquired UTIs in adult women mainly in the United State (Smith et al., 2008) and also accounted for $51 \%$ of UTI cases at the University health centre in Michigan (Amee et al., 2001). The chuA gene is part of the heme transport locus, which appears to be widely distributed among pathogenic E. coli strains. Prevalence of $\operatorname{ch} u A$ gene in most of the representative isolates in the study may be a pointer to the significance of iron acquisition in the pathogenesis and urovirulence of UPEC. Greater percentage $(60 \%)$ of isolates in the study belonged to phylogroup D hence, corroborates the reports of Yanping et al. (2012) who reported that the predominant group of UPEC recovered from UTI patients in their study belonged to phylogroup D. The finding also agrees with the report of Cao et al. (2011), in a multicenter study in China, where larger percentage (54\%) 
the UPEC isolated from both first time and recurrent UTI cases were from phylogenetic group D. Similarly, the present study corroborates Johann et al. (2005) reports. In their findings, $35(63 \%)$ out of the 56 UTIs E. coli characterized belonged to phylogroup D, 2 (4\%) to group B1 and only 1 isolate belonged to group B2.

Recognizable proportion of UPEC typed in this study were in group A and few in group B1 lineage. Similar case where ExPEC strains were isolated from UTI patients in Russia were dominated by groups A and B1 (Moreno et al., 2008). Extra-intestinal uropathogenic E. coli belonging to groups A and B1 has been reported to preferentially infect immuno-compromised hosts (Moreno et al., 2008), and are associated with specific blood group antigens and the non-secretor phenotypes (Hooton et al., 1996). The YjaA gene is involved in E. coli cellular response to hydrogen peroxide, cadmium and acid stress as well as involved in biofilm formation (Gordon et al., 2008)

Although most of the UPEC implicated in various cases of UTIs were believed to be highly concentrated in group B2 (Moreno et al., 2009; Codruța-Romaniţa et al., 2011; Skjøt-Rasmussen et al., 2011). Non-detection of group B2 strains in this study may be due to differences in geographical locations and temporal variation as well as specific features of the population. Moreover, it could also be attributed to the enormous diverse pool of $E$. coli species (Bailey et al., 2010), or the bacterial characteristics in different topographical arena under the influence of antibiotics usage or the host genetic factor (Duriez et al., 2001).

Resistance problem is now recognized as having a prominent clonal component attributable to the emergence and dissemination of specific antibiotic resistant clonal group of ExPEC ((Johnson et al., 2010). The report of the clonal group of UPEC in pregnant women with UTI in this study is unique and appears to be the first of its kind in the study areas.

\section{Conclusion}

The study shows that the prevalence of multi-antibiotic resistant uropathogenic E. coli mediated urinary tract infections in the study area is high and Escherichia coli belonging to phylogenetic group D appears to be a predominant uropathogen.

\section{Acknowledgements}

Authors thank the Staff and Head of Department of Molecular Biology and Biotechnology Division of the Nigerian Institute of Medical Research, Lagos, and the Chief Medical Directors and the laboratory scientists of the various hospitals used.

\section{References}

Abbo, L. M., \& Hooton, T. M. (2014). Antimicrobial stewardship and urinary tract infections. Antibiotics, 31, 74-192. http://dx.doi.org/10.3390/antibiotics3020174

Abid, S., Sohail, A., \& Muhammad, A. H. (2013). Prevalence and antimicrobial susceptibility of gram negative bacteria isolated from urinary tract infections. J Infect Mol Biol, 1(2), 35-37. http://www.nexusacademi cpublishers.com/journal/2

Amaeze, N. J., Abah, A. U., \& Okoliegbe, I. N. (2013). Prevalence and antibiotic susceptibility of uropathogens among patients attending University of Abuja Teaching Hospital, Gwagwalada, Abuja. Intern J Medicin Med Sci, 5(10), 460-466. Retrieved from http://www.academicjournals.org/IJMMS

Arisoy, M., Aysev, D., Ozel, D., Köse, S. K., Ozsoy, E. D., \& Akar, N. (2006). Detection of virulence factors of Escherichia coli from children by multiplex polymerase chain reaction. International J Clin Pract, 60, 170-173. http://dx.doi.org/ 10.1111/j.1742-1241.2005.00668.x

Bahadin, J., Teo, S., \& Mathew, S. (2011). Aetiology of community-acquired urinary tract infection and antimicrobial susceptibility patterns of uropathogens isolated. Singapore Med J, 52(6), 415-420.

Bailey, J. K., Pinyon, J. L, Anantham, S., \& Hall, R. M. (2010). Commensal Escherichia coli of healthy humans: a reservoir for antibiotic-resistance determinants. J Med Microbiol, 59, 1331-1339. http://dx/doi.org/10.1099/ jmm.0.022475-0

Bower, J. M., Eto, D. S., \& Mulvey, M. A. (2005). Covert operations of uropathogenic Escherichia coli within the urinary tract. Traffic, 6, 18-31. http://dx.doi.org/ 10.1111/j.1600-0854.2004.00251.x

Cao, X., Cavaco, L. M., Lv, Y., Li, Y., Zheng, B., Wang, P., ... Aarestrup, F. M. (2011). Molecular characterization and antimicrobial susceptibility testing of Escherichia coli isolates from patients with urinary tract infections in 20 Chinese hospitals. J Clin Microbiol, 49, 2496-2501. http://dx.doi.org/ 10.1128/JCM.02503-10. 
Caracciolo, A., Bettinelli, A., Bonato, C., Isimbaldi, C., Tagliabue, A., Longoni, L., \& Bianchetti, M. G. (2011). Antimicrobial resistance among Escherichia coli that cause childhood community-acquired urinary tract infections in Northern Italy. Italian J Pediatr, 37, 3. http://dx.doi.org/10.1186/1824-7288-37-3

Clermont, O., Bonacorsi, S., \& Bingen, E. (2000). Rapid and simple determination of the Escherichia coli phylogenetic group. Appl Environ Microbiol, 66, 4555-4558. http://dx.doi.org/10.1128/AEM.66.10.45554558.2000 .

Clinical and Laboratory Standards Institute. (2012). Performance standards for antimicrobial susceptibility testing. 22nd informational supplement, M100-S22. Wayne, PA.

Codruța-Romanița, U., Grigore, L. A., Georgescu, R. M., Bãltoiu, M. C., Condei, M., \& Teleman, M. D. (2011). Phylogenetic background and extraintestinal virulence genotypes of Escherichia coli vaginal strains isolated from adult women. Revis Românăde Medici Laborator, 19(1/4), 37-45.

Diard, M., Garry, L., Selva, M., Mosser, T., Denamur, E., \& Matic, I. (2010). Pathogenicity-associated islands in extraintestinal pathogenic Escherichia coli are fitness elements involved in intestinal colonization. $J$ Bacteriol, 192(19), 4885-4893. http://dx.doi.org/10.1128/JB.00804-10.

Duriez, P., Clermont, O., Bonacorsi, S., Bingen, E., Chaventre, A., Elion, J., ... Denamur, E. (2001). Commensal Escherichia coli isolates are phylogenetically distributed among geographically distinct human populations. Microbiol, 147, 1671-1676.

Ehsan, V., Roya, N., Ali, A., Farshid, K., Reza, N., \& Rasool, H. (2013). The Last Three Years Antibiotic Susceptibility Patterns of Uropathogens in Southwest of Iran. Jundishapur J Microbiol, 6(4), 1-5. http://dx.doi.org/10.5812/jjm.4958

Farmer, J. J. (1999). Enterobacteriaceae: Introduction and Identification. In P. R. Murray, E. J. Baron, M. A. Pfaller, F. C. Tenover, \& R. H. Yolken (Eds.). Manual Clin Microbiol (pp. 442-450). Washington, D.C.

Foxman, B. (2002). Epidemiology of urinary tract infections: incidence, morbidity and economic costs. American J Medicin, 113, 55-13. http://dx.doi.org/10.1016/S0002-9343(02)01054-9

Griebling, T. L. (2005) Urologic Diseases in American Project: Trends in Resource Use for Urinary Tract Infections in Women. J Urology, 173(4), 1281-1287.

Herzer, P. J., Inouye, S., Inouye, M., \& Whittam, T. S. (1990), Phylogenetic distribution of branched RNA-linked multi-copy single-stranded DNA among natural isolates of Escherichia coli. J Bacteriol, 172, 6175-6181. http://dx.doi.org/0021-9193/90/116175-07\$02.00/0.

Hooton, T. M., Scholes, D., Hughes, J. P., Winter, C., Roberts, P. L., Stapleton, A. E., .. Stamm, W. D. (1996). A prospective study of risk factors for symptomatic urinary tract Infection in young women. New England $J$ Medicin, 335, 468-474. http://dx.doi.org/10.1056/NEJM199608153350703

Johann, D. D. P., Laupland, K. B., Church, D. L., Menard, M. L., \& Johnson, J. R. (1996). Virulence factors of Escherichia coli Isolates that produce CTX-M-Type extended-spectrum $\beta$-lactamases. Antimicrob Agents Chemothe, 49(11), 4667-4670. http://dx.doi.org/10.1128/AAC.49.11.4667-4670.2005.

Johnson, J. R. I., \& Russo, T. A. (2005). Molecular epidemiology of extraintestinal pathogenic (uropathogenic) Escherichia coli. Int J Med Microbiol, 295(6-7), 383-404. http://dx.doi.org/10.1128/JCM.00949-08.

Johnson, J. R., Johnston, B., Clabots, C., Kuskowski, M. A., \& Castanheira, M. ( 2010). Escherichia coli sequence type ST131 as the major cause of serious multidrug-resistant E. coli infections in the United States. Clin Infect Dis, 51, 286-294. http://dx.doi.org/10.1086/653932

Kashef, N., Djavid, G. E., \& Shahbazi, S. (2010). Antimicrobial susceptibility patterns of community-acquired uropathogens in Tehran, Iran. J Infect Develop Countries, 4, 202-206.

Kolawole, A. S., Kolawole, O. M., Kandaki-Olukemi, Y. T., Babatunde, S. K., Durowade, K. A., \& Kolawole, C. F. (2009). Prevalence of urinary tract infections (UTI) among patients attending Dalhatu Araf Specialist Hospital, Lafia, Nasarawa State, Nigeria. Intern J Medicin and Med Sci, 1, 163-167. Retrieved from http://www.academicjournals.org/ijmms.

Lee, S. J., Lee, D. S., Choe, H. S., Shim, B. S., Kim, C. S., Kim, M. E., \& Cho, Y. H. (2011). Antimicrobial resistance in community-acquired urinary tract infections: results from the Korean antimicrobial resistance monitoring system. J Infect Chemother; 17(3), 440-6. http://dx.doi.org/10.1007/s10156-010-0178-x. 
Lilian, M., Abbo, L. M., \& Hooton, T. M. (2014). Antimicrobial stewardship and urinary tract infections. Antibiotics, 3, 174-192. http://dx.doi.org/10.3390/antibiotics3020174

Manjula, N. G., Girish, C. M., Shripad, A. P., Subhashchandra, M. G., \& Channappa, T. S. (2013). Incidence of urinary tract infections and its aetiological agents among pregnant women in Karnataka region. Advan Microbiol, 3, 473-478. http://dx.doi.org/http://dx.doi.org/10.4236/aim.2013.36063.

Marrs, C. F., Zhang, L., \& Foxman, B. (2005). Escherichia coli mediated urinary tract infections: are there distinct uropathogenic E. coli (UPEC) pathotypes? FEMS Microbiol Lett, 252, 183-190. http://dx.doi.org/10.1016/j.femsle.2005.08.028

Moreno, E., Andreu, A., Pigrau, C., Kuskowski, M. A., Johnson, J. R., Prats, G. (2008). Relationship between Escherichia colistrains causing acute cystitis in women and the fecal E. coli population of the host. $J$ Clin Microbiol, 46, 2529-2534. http://dx.doi.org/ 10.1128/JCM.00813-08

Morioka, A., Asai, T., Ishihara, K., Kojima, T. Y., \& Takahashi, T. (2005). In vitro of 24 antimicrobial agents against Staphylococcus and Steptococcus isolated from diseased animals in Japan. J Veter Med Sci., 67, 207-210.

National Institutes of Health (NIH). (2004)). Fact Sheet: What I need to know about urinary tract infections. NIH Publication No. 04-4807.

Sabat, A. J., Budimir, A., Nashev, D., Sá-Leão, R., van Dijl, J. M., Laurent, F., ... Friedrich, A. W. (2013). Overview of molecular typing methods for outbreak detection and epidemiological surveillance. Eurosurveillance, 18(4), 20380. Retrieved from http://www.eurosurveillance.org/ViewArticle.aspx? ArticleId $=20386$

Schneeberger, C., Kazemier, B. M., \& Geerlings, S. E. (2014). Asymptomatic bacteriuria and urinary tract infections in special patient groups: Women with diabetes mellitus and pregnant women. Curr. Opin. Infect. Dis, 27, 108-114. http://dx.doi.org/10.1097/QCO.0000000000000028

Sharma, M., Aparna Yadav, S., \& Chaudhary, U. (2009). Biofilm production in uropathogenic Escherichia coli. Indian J Pathol Microbiol, 52, 294-294. http://dx.doi.org/http://www.ijpmonline.org/text.asp?2009/52/2/ $294 / 48960$

Skjøt-Rasmussen, L., Hammerum, A. M., Jakobsen, L., Lester, C. H., Larsen, P., \& Frimodt-Møller, N. (2011). Persisting clones of Escherichia coli isolates from recurrent urinary tract infection in men and women. $J$ Med Microbiol, 60, 550-554. http://dx.doi.org/10.1099/jmm.0.026963-0.

Tamalli, M., Bioprabhu, S., \& Alghazal, M. A. (2013). Urinary tract infection during pregnancy at Al-khoms, Libya. Intern J Medicin Med Sci, 3(5), 455-459.

Yamamoto, S. (2007). Molecular epidemiology of uropathogenic Escherichia coli. J Infect Chemother; 13, 68-73. http://dx.doi.org/10.1007/s10156-007-0506-y.

Yanping. L., Yanning, M., Qiang. Z., Leili, W., Ling, G., Liyan, Y., ... Jiyong Y. (2012). Similarity and Divergence of Phylogenies, Antimicrobial Susceptibilities, and virulence factor profiles of escherichia coli isolates causing recurrent urinary tract infections that persist or result from re-infection. J Clin Microbiol, 50(12), 4002-4007. http://dx.doi.org/10.1128/JCM.02086-12.

Yuksel, S., Ozturk, B., Kavaz, A., Ozcakar, Z. B., Acar, B., Guriz, H., Aysel, D., Ekim, M., Yalcinkaya, F. (2006). Antibiotic resistance of urinary tract pathogenns and evaluation of empirical treatment in Turkish children with urinary tract infections. Intern $J$ Antimicrob Agents, 28(5), 413-6. http://dx.doi.org/10.1016/j.jjantimicag.2006.08.009

\section{Copyrights}

Copyright for this article is retained by the author(s), with first publication rights granted to the journal.

This is an open-access article distributed under the terms and conditions of the Creative Commons Attribution license (http://creativecommons.org/licenses/by/3.0/). 